\author{
А.І. Сергієнко ${ }^{1}$, В.І. Нікітченко ${ }^{1}$, Д.В. Башинський ${ }^{2}$, А.Г. Дмитрієв ${ }^{3}$ \\ ${ }^{1}$ Державний науково-дослідний інститут випробувань \\ і сертифікаиії озброєння та військової техніки, Чернігів \\ ${ }^{2}$ Державний науково-дослідний інститут авіаиії, Київ \\ ${ }^{3}$ Харківський національний університет Повітряних Сил ім. І. Кожедуба, Харків
}

\title{
ОПТИМІЗАЦІЯ ЗАКОНІВ ПОЗДОВЖНЬОГО КОНТУРУ УПРАВЛІННЯ КЕРОВАНОЇ АВІАЦІЙНОЇ БОМБИ ЗА РЕЗУЛЬТАТАМИ ЧИСЕЛЬНОГО МОДЕЛЮВАННЯ ПОЛЬОТУ В ТУРБУЛЕНТНІЙ АТМОСФЕРІ
}

\begin{abstract}
Стаття присвячена пошуку шляхів оптимізації закону управління керованої авіаційної бомби з метою досягнення найкращзих точносних показників при польоті в турбулентній атмосфері. Проведено моделювання польоту керованої авіачійної бомби в турбулентній атмосфері з урахуванням білого шуму (неточності) по сигналам управління та запізнення в контурі управління. За результатами аналізу близько 800 модельних експериментів побудовано залежності середньоквадратичного значення промаху та критеріїв запасу стійкості від значень коефіцієнтів підсилення в контурах управління (позиційному, диференціальному та інтегральному). Використані в прочесі модельних експериментів критерї стійкості поздовжнього руху дозволили оптимізувати закон управління керованою авіаційною бомбою та досягнути максимально можливої точності ураження при польоті у турбулентній атмосфері. Запропоновані часткові критерії, за якими проводиться аналіз та оптимізачія закону управління в поздовжньому контурі. Визначено очікувані характеристики точності керованої авіачійної бомби з оптимальним законом управління в умовах турбулентної атмосфери.
\end{abstract}

Ключові слова: керована авіаџійна бомба, закони управління, турбулентність атмосфери, точність.

\section{ВСТУП}

Постановка проблеми. Аналіз бойових дій в Сирійській Арабській Республіці доводить, що за рахунок сучасного управління військами та сучасної високоточної зброї можливо досягти значних результатів операції навіть відносно невеликою чисельністю військового угрупування [1]. Керовані авіаційні бомби (КАБ) є одним з видів високоточної зброї, вони поєднують у собі високу точність, потужність бойової частини і відносно низьку вартість [2].

На теперішній час в Україні активно ведуться роботи по продовженню призначених показників, модернізації та розробці зразків КАБ та їх складових частин (систем керування, головок самонаведення тощо). В комплексі цих робіт приймає участь і Державний науково-дослідний інститут випробувань i сертифікації озброєння та військової техніки, так на замовлення Командування Повітряних Сил Збройних Сил України було проведено науково-дослідну роботу (НДР). Одним з питань, які досліджувались в ході цієї НДР, було моделювання польоту КАБ 3 метою оптимізації аеродинамічного компонування і аналізу стійкості та керованості КАБ. В ході дослідження стійкості та керованості КАБ при проведенні НДР розроблено методику оптимального розміщення аеродинамічних поверхонь, однак вплив турбулентності атмосфери не досліджувався.

Зростання інформаційно-комунікаційних технологій привело до широкого використання цифрових контролерів у сучасних системах автоматики. Простота реалізації, невелика вартість та малі габарити - все це привело до заміни класичних аналогових регуляторів цифровими. Однак, не дивлячись на відносно високу швидкодію сучасні контролери, через складність алгоритму управління, можуть викликати вкрай небажане запізнювання [3].

На сьогоднішній день практично немає задовільних рішень, пов'язаних 3 синтезом регуляторів в умовах часового запізнювання та збурень. Задача компенсації зовнішніх збурювань відноситься до фундаментальних проблем сучасної теорії автоматичного управління. [4] Одним 3 напрямів досліджень $€$ створення адаптивних пропорційно-інтегрально-диференціальних

регуляторів на основі нейронних мереж. Такі регулятори можуть підлаштовувати коефіцієнти під зовнішні умови, що змінюються [5]. Оскільки КАБ по своїй суті є однорежимним і одноразовим літальним апаратом [6], розробка нейронного регулятора не має під собою грунту через те, що за досить короткий 
політ нейронна мережа може не встигнути самонавчитися. Тому, в розвиток досліджень, які були проведені в ході вищевказаної НДР, метою статті є розробка критеріїв, за якими можливо в процесі чисельного моделювання оптимізувати закони управління КАБ при польоті в турбулентній атмосфери та оцінити точносні характеристики КАБ.

\section{Виклад основного матеріалу}

У якості об'єкту управління для моделювання було обрано варіант модульного виконання КАБ, до складу якої входили:

- авіаційна бомба типу ФАБ-250-270;

- блок аеродинамічного управління 3 рулями, який закріплено в носовій частині бомби;

- хрестовидне крило.

Загальний вигляд об'єкту моделювання показано на рис. 1. Аеродинамічні характеристики елементів при польоті КАБ, які моделювалися на дозвукових швидкостях, визначались наступним чином. Для крила та рулів похідна підйомної сили по куту атаки визначалась по залежності від числа М, яка показана на рис. 2. Коефіцієнт опору при нульовій підйомній силі визначено з урахуванням рекомендацій [7]. Коефіцієнт профільного опору визначено за формулою:

$$
C_{x p}=2 C_{f} \eta_{c},
$$

де $2 C_{f}-$ подвоєний коефіцієнт тертя пласкої пластинки;

$\eta_{c}-$ коефіцієнт, що враховує товщину профілю крила. Для крила, що моделюється дорівнює 1,03.

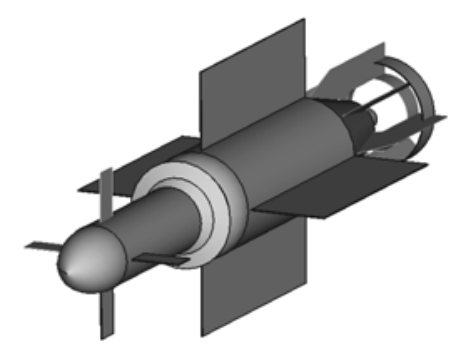

Рис. 1. Загальний вигляд об’єкту моделювання

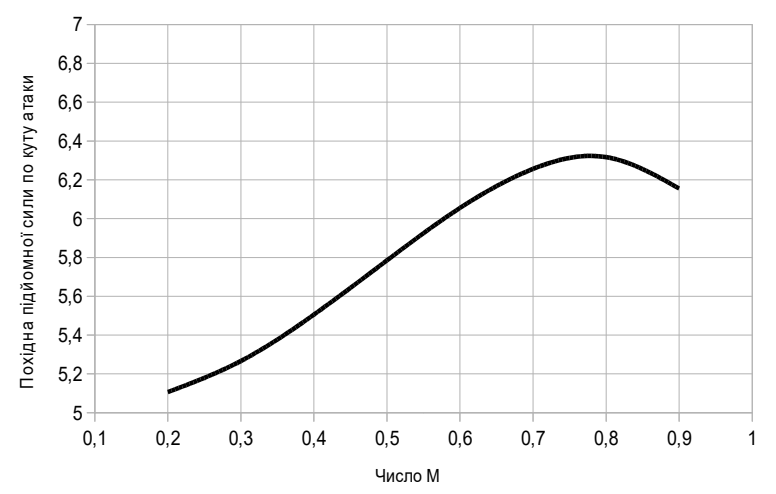

Рис. 2. Залежність похідної по куту атаки від числа $M$ для крила та рулів
В діапазоні висот (до 11000 м) та швидкостей польоту $(0,5<\mathrm{M}<0,9)$ для крила, що досліджується $(\mathrm{CAX}=0,7$ м), числа Рейнольдса матимуть значення від $0,5 \cdot 10^{7}$ до $1,0 \cdot 10^{7}$, а координата переходу ламінарної течії у межовому шарі на турбулентну 0,2 - 0,4 метри. Для цих параметрів значення подвоєний коефіцієнт тертя пласкої пластинки буде в межах 0,004-0,0045. Враховуючи, що моделювання передбачає політ на докритичних числах М [6], хвильовий опір крила припустимо прийняти відсутнім. Аеродинамічний коефіцієнт індуктивного опору визначався за формулою:

$$
C_{x t}=\left(C_{y}+C_{x 0} \sin (\alpha)\right) \tan (\alpha) .
$$

В формулі 2 мається на увазі місцевий кут атаки для крила та руля.

Аеродинамічні характеристики авіаційної бомби калібру 250 кг представлені у вигляді коефіцієнтів:

$C_{x 0}$ - коефіцієнт лобового опору при умові нульової підйомної сили;

$C_{x}^{a^{2}}$ - похідна аеродинамічного коефіцієнту індуктивного опору по куту атаки;

$C_{y}^{a}$-похідна коефіцієнту підйомної сили по куту атаки;

$m_{z}^{a}-$ коефіцієнт моменту по куту атаки відносно осі Z;

$m_{z}^{\omega z}-$ коефіцієнт демпфіруючого моменту при повздовжньому русі.

Для блоку аеродинамічного управління аеродинамічні характеристики взяті аналогічні авіаційній бомбі калібру 250 кг за винятком поправки на відсутність донного опору при визначення коефіцієнту опору при нульовій підйомній силі. Моменти аеродинамічних сил, що діють на КАБ у польоті визначалися за результатами розрахунку центру мас КАБ в цілому, моментів інерції КАБ в цілому, положення фокусів аеродинамічних поверхонь та величини аеродинамічних сил на кожному кроці моделювання [8]. Параметри атмосфери моделювалися відповідно до залежностей, вказаних у [9] та [10].

Для визначення атмосферного тиску на заданій геопотенціальній висоті використовується формула:

$$
\ln p_{H}=\ln p_{c}-\frac{g_{c}}{\beta R} \ln \frac{T_{c}+\beta H}{T_{c}},
$$

де $p_{c}$ - атмосферний тиск на середньому рівні моря - 101325 Па;

$g_{c}-$ стандартне прискорення вільного падіння на середньому рівні моря - 9,80665 м/с2;

$T_{c}$ - температура на середньому рівні моря $288,15 \mathrm{~K}$;

$R$ - питома газова постійна - 287,05287; 
$\beta=\frac{d T}{d H}-$ градієнт термодинамічної температури по геопотенціальній висоті - “мінус" 0,0065 K/M.

Співвідношення між геометричною та геопотенціальною висотою наступне:

$$
H=\frac{r h}{r+h},
$$

де $h$ - геометрична висота, м;

$r=6356767$ м - умовний радіус Землі.

Температура повітря на заданій висоті:

Щільність повітря на заданій висоті польоту

$$
T_{H}=T_{0}+\beta H
$$

визначається відповідно до рівняння стану ідеального газу:

$$
\rho_{H}=\frac{\rho_{H}}{R T_{H}} .
$$

Швидкість звуку обчислюється за формулою:

$$
\alpha=20,046796 \sqrt{T_{H}} .
$$

При моделюванні атмосферної турбулентності враховувались рекомендації [11]. Частота виникнення вертикальних поривів розраховувалась через масштаб турбулентності та швидкість польоту КАБ. Інтегральний масштаб турбулентності прийнятий 760 м, тобто зміна вертикального пориву моделювалася через кожні 760 м горизонтальної складової пройденого шляху. Вертикальний порив моделювався нормально розподіленою випадковою величиною 3 середнім квадратичним значенням вертикального пориву 0,3 м/с для слабої турбулентності, 1 м/с - для помірної та 3 м/с - для інтенсивної турбулентності.

Вплив атмосферної турбулентності на політ КАБ моделювався, як прирощення кута атаки $\Delta \alpha$ :

$$
\Delta \alpha=\arcsin \left(\frac{W}{V}\right)
$$

де $W$ - швидкість вертикального пориву, м/с;

$V$ - повітряна швидкість літального апарату, м/с.

При проведенні чисельних експериментів білий шум (похибка визначення параметрів) на вході в систему управління КАБ моделювався рівномірно розподіленою випадковою величиною в інтервалі \pm 3 \% від заміряної величини, затримка сигналу на вході в систему управління складала 0,5 с. Модель обчислювача системи автоматичного управління уявляла собою позиційно-, інтегрально-, диференціальний регулятор. На відміну від класичного ПІД-регулятора в управління диференційною частиною використовувався сигнал не похідної похибки управління, а сигнал кутової швидкості обертання. Це дозволяло досягти більш якісної кутової стабілізації КАБ. В процесі моделювання поздовжнього руху використовувався наступний закон управління:

$$
\frac{d \delta_{P B}}{d t}=k_{P}(\varepsilon-0)-k_{d} \dot{\vartheta}+k_{i} \int_{0}^{t}(\varepsilon-\theta) d t,
$$

де $\delta_{P B}-$ кут відхилення руля висоти, рад.;

$\varepsilon$ - кут місця цілі, рад.;

$\theta$ - кут нахилу траєкторії КАБ, рад.;

$\dot{\vartheta}-$ кутова швидкість тангажу, $\mathrm{c}^{-1}$;

$k_{P}, k_{d}, k_{i}-$ коефіцієнти підсилення у позиційній, диференціальній та інтегральній складовій закону управління у поздовжньому каналі.

Для задачі моделювання поздовжнього руху КАБ використовувалась наступна система рівнянь [4]:

$$
\begin{aligned}
& m \frac{d v}{d t}=-X-G \sin \theta ; \\
& m V \frac{d \theta}{d t}=Y-G \cos \theta ; \\
& I_{z} \frac{d \omega_{z}}{d t}=M_{z} ; \\
& \frac{d \vartheta}{d t}=\omega_{z} .
\end{aligned}
$$

де $X, Y$ - сили, що діють на виріб по напрямкам осей швидкісної системи координат, Н;

$M$ - сума моментів всіх сил відносно відповідних осей зв'язаної 3 виробом системи координат, Н м; $\omega_{z}$ - кутові швидкості відносно відповідних осей зв'язаної 3 виробом системи координат, $\mathrm{c}^{-1}$;

$V$ - повітряна швидкість центру мас, м/с;

$m$ - маса виробу, кг;

I - моменти інерції виробу відносно головних осей інерції, кг м²;

$\theta$-кут нахилу траєкторії до горизонту, градуси;

$\vartheta$-кут тангажа відносно земних осей координат, град.

Блок-схема алгоритму моделювання показана на рис. 3 .

Критеріями точності бомбометання було математичне сподівання та середнє квадратичне відхилення промахів за результатами 30 реалізацій моделювання скидання КАБ в однакових умовах [12].

При моделюванні було обрано наступні початкові умови:

- висота скидання КАБ 10000 м від рівня моря;

- перевищення над ціллю - 10000 м;

- дальність до цілі 35 км;

- індикаторна швидкість при скиданні 500 км/год;

- скидання відбувається у сталому горизонтальному польоті.

Приклад зміни параметрів в ході польоту КАБ, які визначені за результатами моделювання показано на рис. 4. 


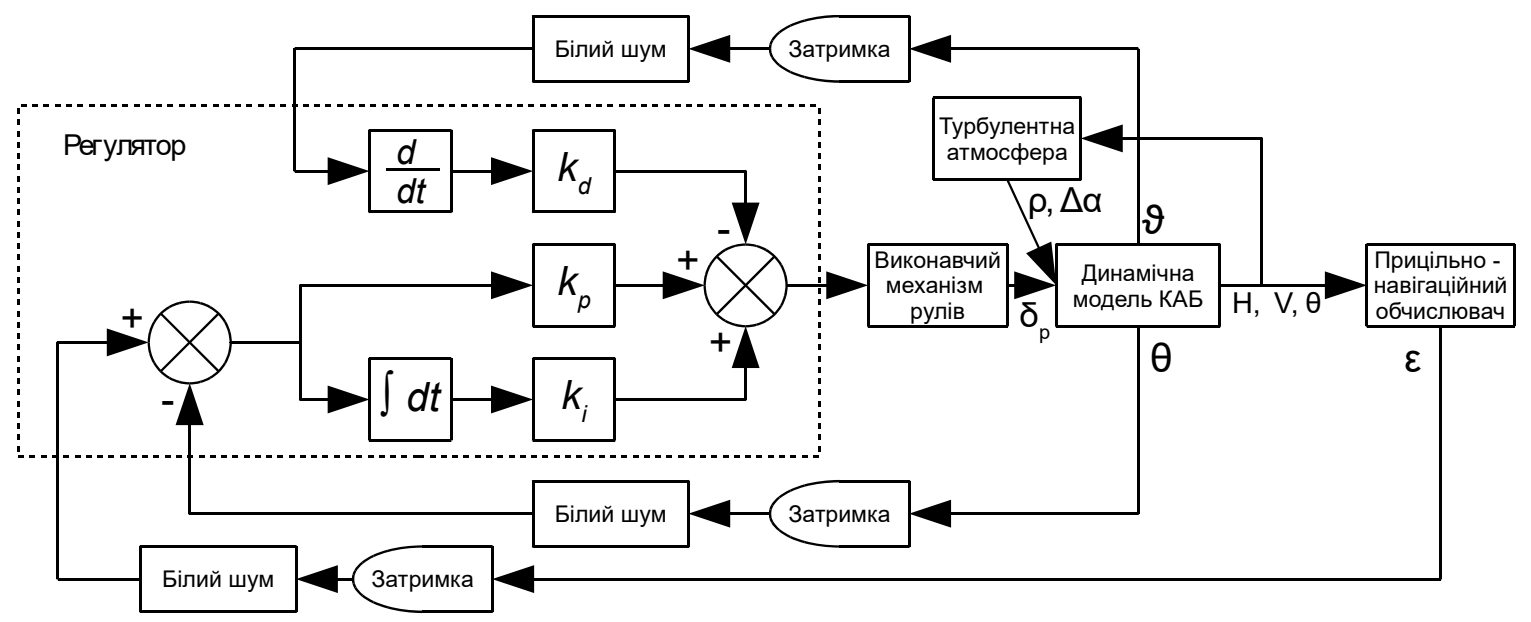

Рис. 3. Блок-схема алгоритму моделювання

Для оцінки якості траєкторної стабілізації КАБ у польоті використовувався середній квадрат кутової швидкості по куту нахилу траєкторії, який характеризує енергію коливального руху КАБ в довгоперіодичному поздовжньому русі:

$$
M S \dot{\theta}=\frac{1}{n} \sum_{i=1}^{n}\left(\frac{d \theta}{d t}\right)^{2} .
$$

Для оцінки якості кутової стабілізації КАБ у польоті використовувався середній квадрат кутової швидкості по тангажу, який характеризує енергію коливального руху КАБ в короткоперіодичному поздовжньому русі :

$$
M S \dot{\vartheta}=\frac{1}{n} \sum_{i=1}^{n}\left(\frac{d \vartheta}{d t}\right)^{2} .
$$

Для оцінки завантаження виконавчого механізму приводу рулів використовувався середній квадрат кутової швидкості відхилення руля висоти, що характеризує складову енергії коливального руху, обумовлену відхиленням органів управління:

$$
M S \dot{\delta}_{P B}=\frac{1}{n} \sum_{i=1}^{n}\left(\frac{d \delta_{P B}}{d t}\right)^{2} .
$$

В процесі виконання модельних експериментів та варіації різних параметрів управління було виявлено, що співвідношення величин $M S \dot{\vartheta}$ та $M S \dot{\delta}$ характеризує короткоперіодичний поздовжній рух КАБ. При $M S \dot{\vartheta}>M S \dot{\delta}$ перехідні процеси мали аперіодичний характер або коливальний, що затухає. При $M S \dot{\vartheta}<M S \dot{\delta}$ розвивалися коливання, що розходяться, тобто замкнутий контур управляння КАБ становився нестійким.
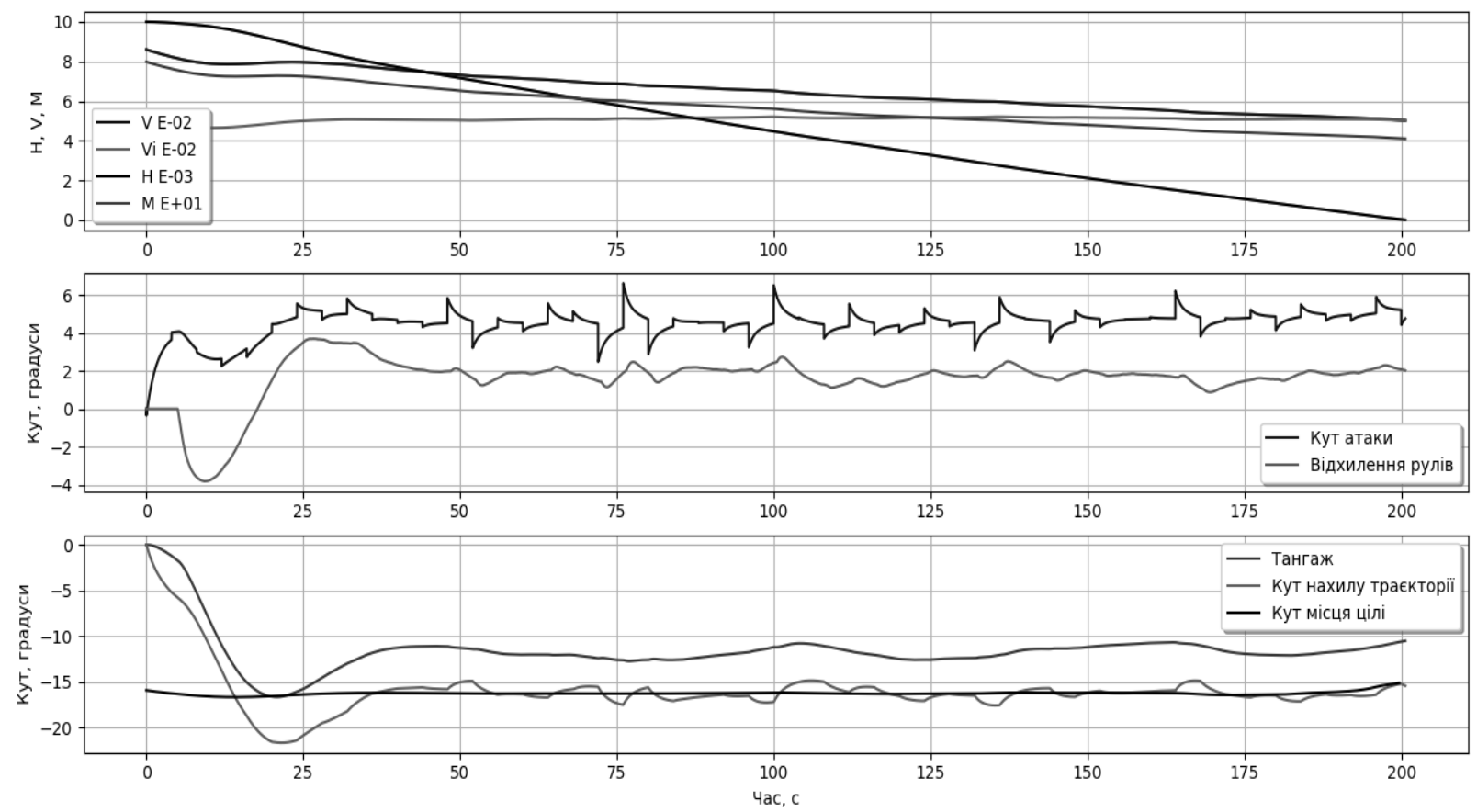

Рис. 4. Характеристики параметрів польоту КАБ 
За результатами цих спостережень було сформульовано критерій запасу стійкості у короткоперіодичному поздовжньому русі:

$$
S T S=\left(1-\frac{M S \dot{\delta}}{M S \dot{\vartheta}}\right) 100 \% .
$$

При від'ємному значенні критерію STS відбувається коливальний рух 3 коливаннями, що розходяться, при нульовому значенні мають місце незатухаючі коливання у короткоперіодичному русі. При збільшенні значення STS відбуваються затухаючі коливання, потім процес становиться аперіодичним.

Для оцінки стійкості польоту у довгоперіодичному поздовжньому русі було сформульовано інший критерій:

$$
S T L=\left(1-\frac{M S \dot{\delta}+M S \dot{\vartheta}}{M S \dot{\theta}}\right)^{2} 100 \% .
$$

Зазначений критерій оцінює запас стійкості при стабілізації на траєкторії. При наближенні його значення до нуля сумарна енергія короткоперіодичного руху дорівнює енергї довгоперіодичного руху, процес стабілізації на траєкторії становиться коливальним, що не затухає (відбувається "розгойдування" по куту нахилу траєкторії). За результатами моделювання було побудовано залежності середньоквадратичного значення промаху та критеріїв запасу стійкості від значень коефіцієнтів підсилення в контурах управління (позиційному, диференціальному та інтегральному). Отримані залежності показані на рис. 5, рис. 6 та рис. 7. За результатами аналізу отриманих залежностей встановлено, що для забезпечення максимальної точності та стійкості польоту КАБ в умовах турбулентності коефіцієнти підсилення у контурах управління повинні бути наступними:

- у позиційному контурі управління $k_{p}=0,95$;

- у диференціальному контурі управління $k_{d}=-6,5$;

- у інтегральному контурі управління $k_{i}=0,08$.

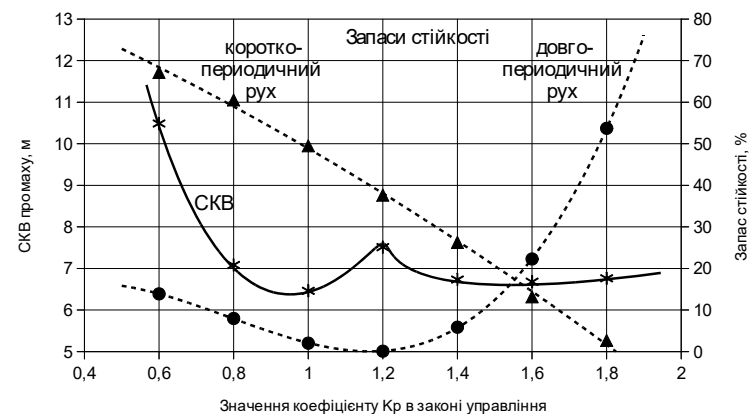

Рис. 5. Залежність СКВ промаху та критеріїв запасу стійкості від значення коефіцієнту підсилення у позиційному контурі управління

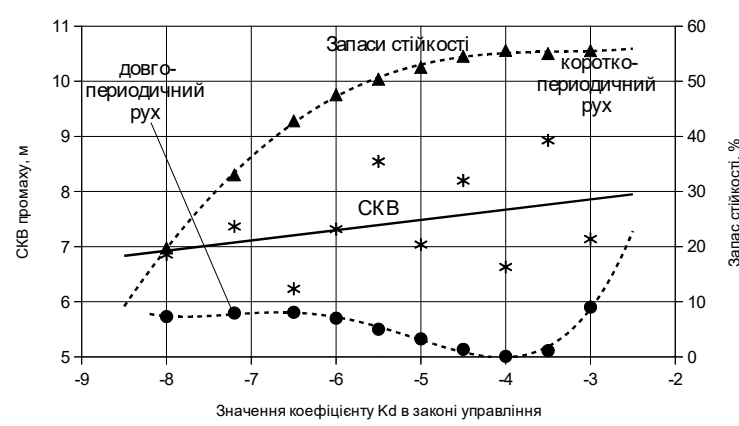

Рис. 6. Залежність СКВ промаху та критеріїв запасу стійкості від значення коефіцієнту підсилення у диференційному контурі управління

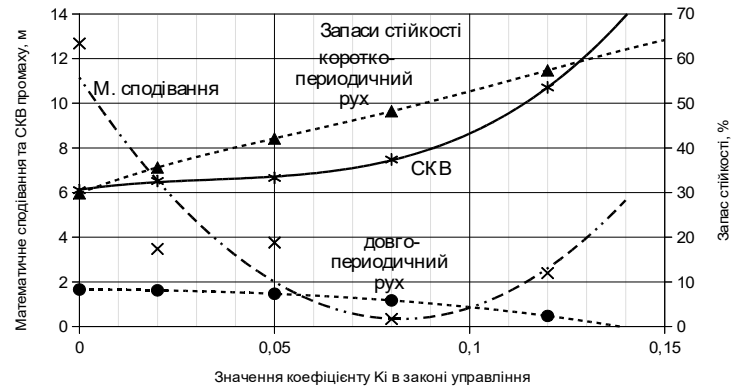

Рис. 7. Залежність математичного сподівання промаху, СКВ промаху та критеріїв запасу стійкості від значення коефіцієнту підсилення у інтегральному контурі управління

При вказаних коефіцієнтах в законі управління середньоквадратичне значення промаху за результатами моделювання (без врахування точності визначення координат навігаційним обчислювачем) становить:

- 7 м в умовах помірної турбулентності;

- 3 м в умовах слабкої турбулентності.

\section{Висновки}

Розроблені математичні моделі керованої авіаційної бомби, системи автоматичного управління та турбулентної атмосфери дозволили провести моделювання та отримати статистично значимі результатів. Усього проведено близько 800 модельних експериментів. Використані в процесі модельних експериментів критерії стійкості поздовжнього руху дозволили оптимізувати закон управління керованою авіаційною бомбою та досягнути максимально можливої точності ураження при польоті у турбулентній атмосфері. Отримані результати можуть бути використані при удосконаленні законів управління, що застосовуються у блоках аеродинамічного управління керованих авіаційних бомб. Доцільно продовжити моделювання 3 метою аналізу впливу на точність ураження точності визначення навігаційних параметрів та затримки сигналів управління. 


\section{Список літератури}

1. Ярош С.П. Аналіз операції угруповання збройних сил російської федерації у Сірійській Арабській Республіці / С.П. Ярош // Наука і техніка Повітряних Сил Збройних Сил України. - 2016. - № 2(16). - С. 13-22.

2. Тараненко В.В. Щодо перспективних напрямків розвитку керованих авіаційних бомб / В.В. Тараненко, Д.В. Башинський // Збірник наукових праць Державного науково-дослідного інституту авіації. - 2018. - № 14(21). - С. 72-76.

3. Попов И. Основы моделирования и системный анализ эффективности боевых авиационных комплексов / И. Попов. - М.: ВВИА им. проф. Н.Е. Жуковского, 1991. - 280 с.

4. Бобцов А.А. Адаптивное и робастное управление с компенсацией неопределенностей / А.А. Бобцов, А.А. Пыркин. - СПб.: НИУ ИТМО, 2013. - 135 с.

5. Стабилизация беспилотного летательного аппарата на основе нейросетевого регулятора / С.С. Андропов, А.В. Гирик, М.Ю. Будько, М.Б. Будько // Научно-технический вестник информационных технологий, механики и оптики. 2016. - № 5(16). - С. 796-800. doi: 10.17586/2226-1494-2016-16-5-796-8001.

6. Красильщиков М.Н. Управление и наведение беспилотных летательных аппаратов на основесовременных информационных технологий / М.Н. Красильщиков, Г.Г. Себряков. - М.: Физматлит, 2003. - 280 с.

7. Лебедев А.А. Динамика полета беспилотных летательных аппаратов / А.А. Лебедев, Л.С. Чернобровкин. - М.: Машиностроение, 1973. - $616 \mathrm{c}$.

8. Соловей Э.Я. Динамика систем наведения управляемых авиабомб / Э.Я. Соловей, А.В. Храпов, ред. Е.С. Шахиджанова.- М.: Машиностроение, 2006. - 328 с.

9. ГОСТ 4401-81 “Атмосфера стандартная. Параметры”. - М., 1982. - 201 с.

10. ICAO Doc 7488/3 “Руководство по стандартной атмосфере ИКАО” [Електронний ресурс]. - 1993. -305 с. - Режим доступу: http://surl.li/evqj.

11. ГОСТ 102514 - 84 "Модель турбулентной атмосферы. Характеристики”.

12. Красильщиков М.Н. Совремнные информационные технологи в задачах навигации и наведения беспилотных маневренных летательных аппаратах / М.Н. Красильщиков, Г.Г. Себряков. - М.: Физматлит, 2009. - 556 с.

\section{References}

1. Yarosh, S.P. (2016), "Analiz operaciyi ugrupovannya zbrojnih sil rosijskoyi federaciyi u Sirijskij Arabskij Respublici" [Analysis of the operation of the armed forces of the Russian Federation in the Syrian Arab Republic], Science and Technology of the Air Force of Ukraine, No. 2(16), pp. 13-22.

2. Taranenko, V.V. and Bashinskij, D.V. (2018), "Shodo perspektivnih napryamkiv rozvitku kerovanih aviacijnih bomb" [Regarding promising areas of development of guided aerial bombs], Collection of Scientific Works State Aviation Research Institute, No. 14(21), pp. 72-76.

3. Popov, I. (1991), "Osnovy modelirovaniya i sistemnyj analiz effektivnosti boevyh aviacionnyh kompleksov" [Fundamentals of modeling and systematic analysis of the effectiveness of combat aircraft systems], VVIA im. prof. N.E. Zhukovskogo, Moscow, $280 \mathrm{p}$.

4. Bobcov, A.A. and Pyrkin, A.A. (2013), “Adaptivnoe i robastnoe upravlenie s kompensaciej neopredelennostej” [Adaptive and robust control with uncertainty compensation], NIU ITMO, St. Petersburg, $135 \mathrm{p}$.

5. Andropov, S.S., Girik, A.V., Budko, M.Yu. and Budko, M.B. (2016), "Stabilizaciya bespilotnogo letatelnogo apparata na osnove nejrosetevogo regulyatora" [Stabilization of an unmanned aerial vehicle based on a neural network regulator], Scientific and technical bulletin of information technologies, mechanics and optics, No 5(16), C. 796-800. doi: 10.17586/2226-1494-2016-16-5796-8001.

6. Krasilshikov, M.N. and Sebryakov, G.G. (2003), "Upravlenie $i$ navedenie bespilotnyh letatelnyh apparatov na osnovesovremenny informacionnyh tehnologij" [Control and guidance of unmanned aerial vehicles based on modern information technologies], Fizmatlit, Moscow, 280 p.

7. Lebedev, A.A. and Chernobrovkin, L.S. (1973), "Dinamika poleta bespilotnyh letatelnyh apparatov" [Unmanned aerial vehicle flight dynamics], Mashinostroenie, Moscow, $616 \mathrm{p}$.

8. Solovej, E.Ya. and Hrapov, A.V. (2006), "Dinamika sistem navedeniya upravlyaemyh aviabomb" [Dynamics of guidance systems for guided bombs], Mashinostroenie, Moscow, 328 p.

9. State Standart 4401-81 (1982), “Atmosfera standartnaya. Parametry" [The atmosphere is standard. Parameters], Moscow, $201 \mathrm{p}$.

10. ICAO Doc 7488/3 (1993), "Rukovodstvo po standartnoj atmosfere IKAO" [ICAO Standard Atmosphere Manual], 305 p., available at: http://surl.li/evqj.

11. State Standart 102514 - 84 "Model turbulentnoj atmosfery. Harakteristiki” [Turbulent Atmosphere Model. Specifications].

12. Krasilshikov, M.N. and Sebryakov, G.G. (2009), "Sovremnnye informacionnye tehnologi v zadachah navigacii i navedeniya bespilotnyh manevrennyh letatelnyh apparatah" [Modern information technologies in the tasks of navigation and guidance of unmanned maneuverable aerial vehicles], Fizmatlit, Moscow, 556 p. 
Відомості про авторів:

\section{Сергіснко Андрій Іванович}

провідний науковий співробітник

Державного науково-дослідного інституту випробувань

і сертифікації озброєння та військової техніки,

Чернігів, Україна

https://orcid.org/0000-0002-1607-6056

Нікітченко Віктор Іванович

кандидат технічних наук

начальник науково-дослідного відділу

Державного науково-дослідного інституту випробувань i сертифікації озброєння та військової техніки,

Чернігів, Україна

https://orcid.org/0000-0001-8973-8711

\section{Башинський Дмитро Володимирович}

ад’юнкт

Державного науково-дослідного інституту авіації,

Київ, Україна

https://orcid.org/ 0000-0002-4949-6225

Дмитрісв Андрій Геннадійович

кандидат технічних наук

старший науковий співробітник

начальник науково-дослідного відділу

Харківського національного університету

Повітряних Сил ім. І. Кожедуба,

Харків, Україна

https://orcid.org/0000-0002-8710-5598
Information about the authors:

\author{
Andrii Serhiienko \\ Lead Research \\ of State Scientific Research Institute of Armament \\ and Military Equipment Testing and Certification, \\ Chernihiv, Ukraine \\ https://orcid.org/0000-0002-1607-6056
}

Viktor Nikitcnenko

Candidate of Technical Sciences

Chief of Section of State Scientific Research Institute

of Armament and Military Equipment

Testing and Certification,

Chernihiv, Ukraine

https://orcid.org/0000-0001-8973-8711

\section{Dmytro Bashynskyi}

Doctoral Student

of State Scientific Research Institute of aviation,

Kyiv, Ukraine

https://orcid.org/ 0000-0002-4949-6225

\author{
Andrii Dmytriiev \\ Candidate of Technical Sciences \\ Senior Research \\ Head of the Scientific Research Department \\ of Ivan Kozhedub Kharkiv \\ National Air Force University, \\ Kharkiv, Ukraine \\ https://orcid.org/0000-0002-8710-5598
}

\title{
ОПТИМИЗАЦИЯ ЗАКОНОВ ПРОДОЛЬНОГО КОНТУРА УПРАВЛЕНИЯ УПРАВЛЯЕМОЙ АВИАЦИОННОЙ БОМБЫ ЗА РЕЗУЛЬТАТАМИ ЧИСЛЕННОГО МОДЕЛИРОВАНИЯ ПОЛЕТА В ТУРБУЛЕНТНОЙ АТМОСФЕРЕ
}

\author{
А.И. Сергиенко, В.И. Никитченко, Д.В. Башинский, А.Г. Дмитриев
}

Статья посвямена поиску путей оптимизачии закона управления управляемой авиационной бомбы с иелью достижения наилучшей точности поражения при полете в турбулентной атмосфере. В статье раскрыт порядок построения экспериментов с численного моделирования полета управляемой авиачионной бомби в турбулентной атмосфере. Описаны аэродинамические характеристики модели управляемой авиационной бомби, законы ее управления и параметры турбулентной атмосферы. Сформулированы и предложены частные критерии за которыми проводится анализ и оптимизация закона управления в продольном контуре. За результатами около 800 модельньх экспериментов построено зависимости среднеквадратического значения промаха и критериев запаса стойкости от значений коэффициентов усиления в контурах управления (позиционном, дифференииальном и интегральном). Использованные в процессе модельных экспериментов критерии стойкости продольного движения позволили оптимизировать закон управления управляемой авиачионной бомбой и достигнуть максимально возможной точности поражения при полете в турбулентной атмосфере. Средне квадратичное значение промаха при применении управляемой авиационной бомбы с дальности 35 км составляет 3 м в условиях слабой турбулентности и 7 м - в условиях умеренной турбулентности. Полученные результаты могут бить использованы при усовершенствовании законов управления, которые применяются в блоках аэродинамического управления управляемых авиационных бомб.

Ключевые слова: управляемая авиационная бомба, законы управления, турбулентность атмосферы, точность.

\section{OPTIMIZATION OF THE LONGITUDINAL - LOOP CONTROL LAWS OF A GUIDED BOMB ACCORDING TO THE RESULTS OF NUMERICAL SIMULATION OF FLIGHT IN A TURBULENT ATMOSPHERE}

\section{A. Serhiienko, V. Nikitcnenko, D. Bashynskyi, A. Dmytriiev}

The article is devoted to the search for ways to optimize the control law of a guided aircraft bomb in order to achieve the best defeat accuracy when flying in a turbulent atmosphere. The article discloses the procedure for constructing experiments with numerical simulation of the flight of a controlled aircraft bomb in a turbulent atmosphere. The aerodynamic characteristics of the model of a guided aircraft bomb, the laws of its control and the parameters of the turbulent atmosphere are described. Particular criteria are formulated and proposed, followed by the analysis and optimization of the control law in the longitudinal contour. Based on the results of about 800 model experiments, the dependences of the root-mean-square value of the slip and the criterion of the safety margin on the values of the gains in the control loops (positional, differential, and integral) were constructed. The longitudinal motion stability criteria used in the process of model experiments made it possible to optimize the control law of a guided aerial bomb and achieve the maximum possible defeat accuracy when flying in a turbulent atmosphere. The root-meansquare miss value when using a guided bomb from a range of $35 \mathrm{~km}$ is $3 \mathrm{~m}$ in conditions of weak turbulence and $7 \mathrm{~m}$ in conditions of moderate turbulence. The results obtained can be used to improve the control laws that are used in aerodynamic control units for guided air bombs.

Keywords: guided aerial bomb, control laws, atmospheric turbulence, accuracy. 